\title{
Shanyn Ould
}

\section{SIN CITY}

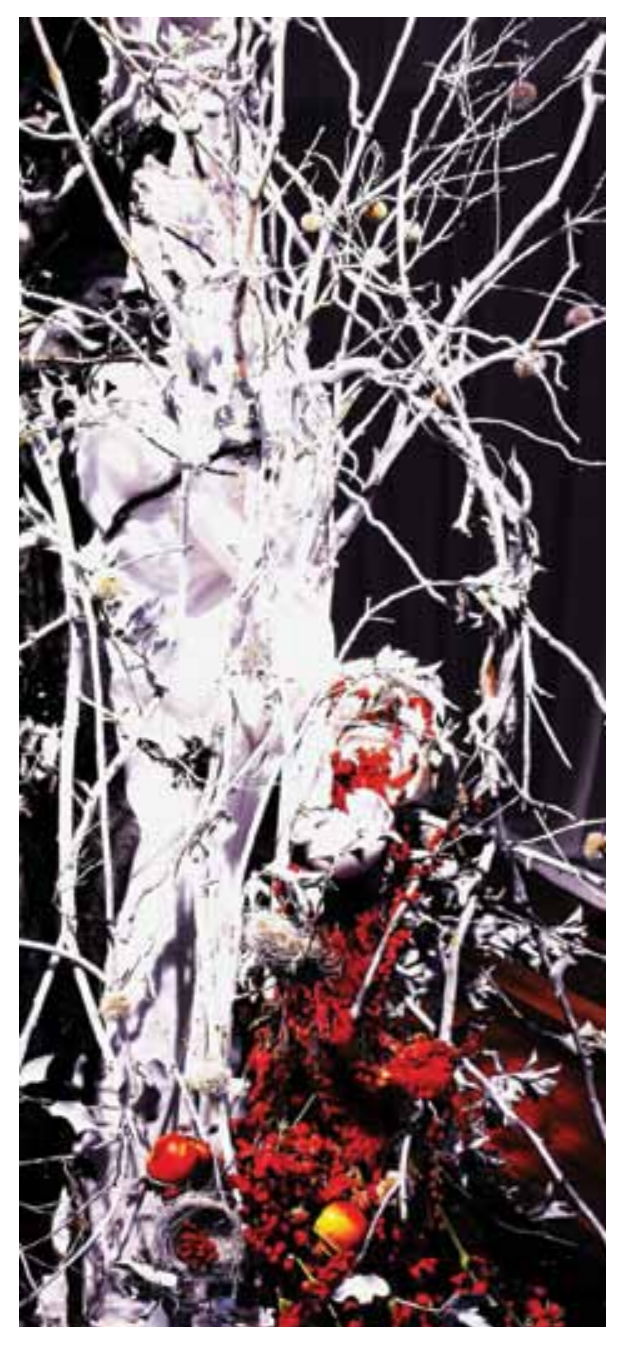

I24 Offset no. Io 